\title{
Sediment transport in the coastal ocean: a retrospective evaluation of the benthic tripod and its impact, past, present and future
}

\author{
RICHARD STERNBERG \\ University of Washington, School of Oceanography, Box 357940, Seattle, WA 98195-7940, \\ E-mail: rws@ocean.washington.edu
}

SUMMARY: In-situ observations of near-bed flow and sediment transport have been carried out for approximately 50 years. The observational technique employs a benthic tripod which can remain submerged on the seafloor for an extended period of time upon which are mounted various oceanographic instruments. The instruments transmit their signals to shipboard via connecting cable or more frequently record their output in accompanying data loggers. During the early years of benthic tripod work, measurements emphasized nearbed current velocity and associated suspended sediment profiles over periods of tidal cycles. The objectives of these studies were to evaluate existing boundary-layer flow and sediment transport theories under natural marine conditions. More recently, instrument capabilities and tripod deployment times have increased dramatically. Research objectives have expanded to include documentation of the physical processes active in the coastal ocean and their contribution to along-and across-margin sediment transport. Tripod-based studies continue to be a significant component of many comprehensive field programs. These long-term studies provide a way to document seabed physical processes and sediment transport over the full range of environmental conditions and continue to shape our concepts of sediment transport on continental shelves. Additionally, these boundary-layer studies have provided critical input for boundary-layernumerical model development. Benthic tripods and self-contained instrumentation also represent a base of expertise that will help with design and implementation of coastal observatories in the future.

Keywords: sediment transport, continental shelves, benthic tripods.

RESUMEN: TRANSPORTE DE SEDIMENTO EN AMBIENTES OCEÁNICOS COSTEROS: UNA EVALUACIÓN RETROSPECTIVA DE LOS TRÍPODES BÉNTICOS Y SU IMPACTO PASADO, PRESENTE Y FUTURO. - Durante los últimos 50 años se han venido desarrollando observaciones in-situ de flujos y transporte de sedimento cercanos al. La técnica observacional de estos estudios consiste en trípodes bénticos sobre los que se instalan diversos instrumentos oceanográficos que quedan sumergidos en el fondo durante un periodo de tiempo mas o menos largo. Los instrumentos pueden transmitir los datos al barco vía una conexión por cable o más frecuentemente registran los datos en unidades de almacenamiento de datos autocontenidas. Al princio, los primeros trabajos con trípodes, se orientaron al estudio de los perfiles de las corrientes y del sedimento en suspensión asociado durante periodos mareales. Los objetivos de estos estudios eran evaluar el flujo en la capa límite de fondo y las teorías de transporte sedimentario en condiciones marinas naturales. Más recientemente, la capacidad de registro y el tiempo de instalación han aumentado de manera espectacular. La investigación con trípodes se ha extendido al estudio de procesos físicos activos en amplias zonas de nuestros océanos y de su contribución al transporte de sedimento a lo largo y a través de los márgenes continentales. Los estudios basados en trípodes continúan siendo un componente importante de muchos programas importantes. Los estudios de larga duración permiten conocer los procesos físicos y el transporte de sedimento en condiciones ambientales muy diversas y contribuyen a mejorar nuestro conocimiento del transporte de sedimento en plataformas continentales. Además, estos estudios de la capa límite han suministrado una información fundamental para el desarrollo de modelos numéricos de la capa límite. Los trípodes bénticos y la instrumentación autocontenida también constituyen una experiencia de base que contribuirá al diseño e implementación de observatorios costeros en un futuro.

Palabras clave: transporte de sedimento, plataforma continental, trípodes bénticos. 


\section{INTRODUCTION}

Marine sedimentologists studying modern physical processes always have had difficulty in interpreting or observing sedimentary conditions in the marine environment. The reasons for this are severalfold. Early geological studies lacked appropriate instrumentation and have historically relied on grain-size distributions and geochemical signatures to interpret marine sedimentary conditions both past and present. Theoretical studies from the 1930s along with observations from laboratory flumes and rivers clearly showed that sediment grains moved primarily near the bed. This further complicated observational techniques and rendered instruments available in those early years ineffective for marinenearbed measurements.

As instrumentation designed for marine use became available through the 1960s, it became possible to make spot, or short-term observations of some important physical parameters (e.g. water level, currents). It was not possible, however, to continue observations over the times when energetic conditions occurred in the sea (e.g. major storms, winter periods) due to ship operational difficulties and instrument limitations.

The advent of micro-electronics with concomitant low power requirements and solid-state characteristics signaled a major revolution in marine instrumentation. Through the 1970s marine instruments and associated control and data logging capabilities were developed which allowed marine scientists to deploy instruments at sea that could (1) remain submerged and operational for extended periods of time; (2) record data internally; and (3) be recalled to the surface by acoustic signals. Among the early users of such technology were physical oceanographers intent on monitoring tides and ocean currents over extended time periods ( $0-1 \mathrm{yr})$ using submerged instruments attached to taut-wire moorings with subsurface floats (e.g. Collins et al., 1966; Hopkins, 1971). Moorings could be deployed and recalled when sea conditions allowed but measurements continued during the extended deployment intervals.

Marine sedimentologists also capitalized on this new instrumentation by building stable platforms to be deployed on the seabed over extended periods. These stable platforms, or "benthic tripods", were self-contained with battery power and recovery floats/ropes connected to acoustic-release mechanisms. A variety of instruments and sensors could be mounted on benthic tripods depending on the study and although the benthic tripod concept has remained relatively unchanged, sensor technology has changed greatly over recent years. Benthic tripods have been used throughout the coastal ocean including inland waters, estuaries, lagoons, and continental shelf and slope environments.

It seems very appropriate to include a retrospective evaluation of the benthic tripod instrumentation system in this special issue commemorating the 50th anniversary of this Journal. The reason for this is because the development and use of benthic tripods began approximately 50 years ago and continues today. The information gained from near-bed observations has greatly improved our concepts of physical processes and associated sediment transport in the sea and results have application that extend into all facets of oceanography, not just marine sedimentology.

\section{METHODS}

Early investigations of marine boundary layers were restricted to the measurement of velocity profiles in the vicinity of the sea floor that extended over minutes to hours (Grace, 1937; Mosby, 1947, 1949; Lesser, 1951; Bowden and Fairbairn, 1952; Duxbury, 1956; Bowden et al., 1959; Charnock, 1959). These studies focused on the nature of velocity profiles and the average values of bed roughness length, bottom shear stress, and the drag coefficient that characterize various shallow marine environments. Accompanying observations of seabed sediment or sediment transport conditions were not carried out.

In the mid-1960s, Sternberg and Creager (1965) described an instrumentation system lowered to the seabed from an anchored ship. The tripod was powered from shipboard and transmitted data signals back to the surface (Fig. 1). This instrumented tripod contained five miniature current rotors within 1.7 meters above the seabed, pressure transducer, suspended sediment samplers, downward-looking video camera and stereo cameras. Sensor signals were previewed and recorded on deck in real time and the tripod could remain submerged at the discretion of the operators.

Although the tripod described by Sternberg and Creager (1965) was an important step in increasing our knowledge of marine boundary layers and associated sediment transport, it was limited in a practi- 


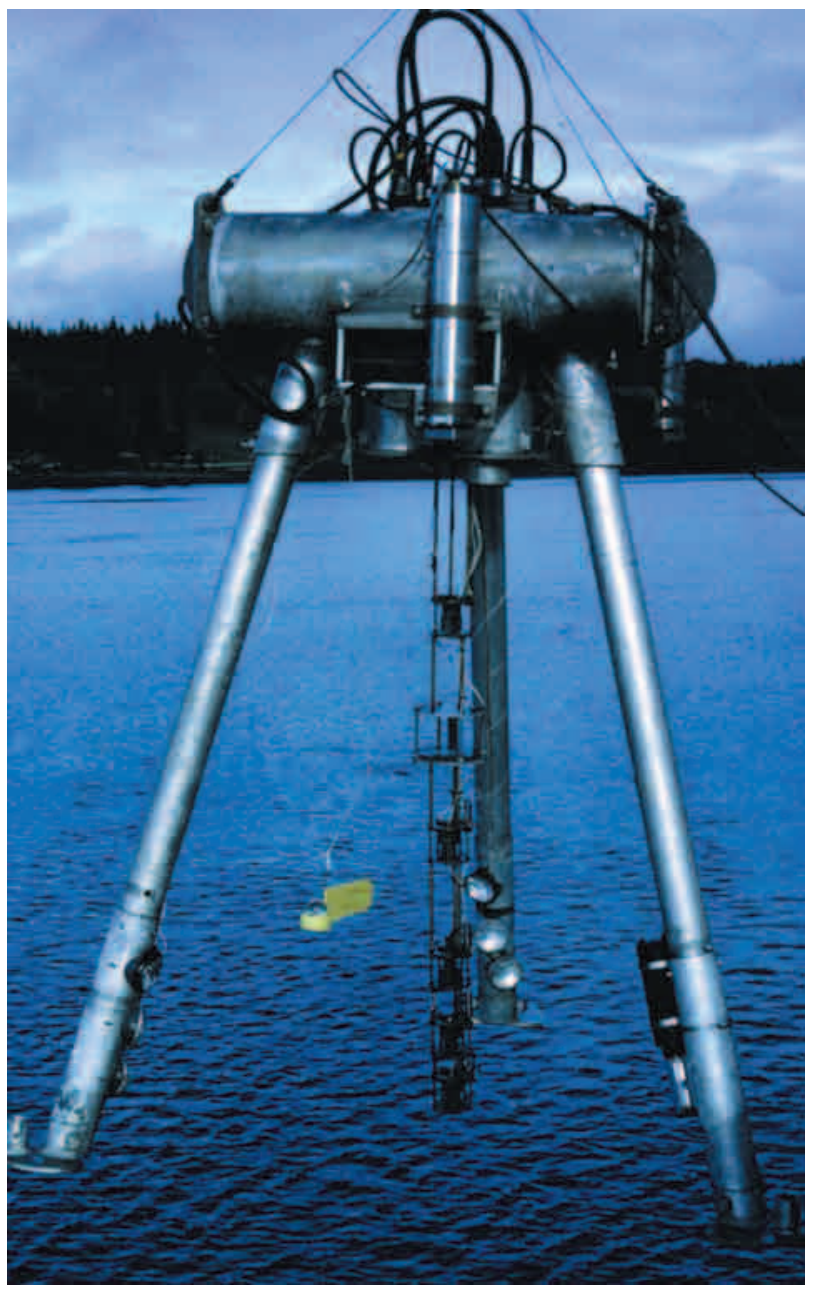

FIG. 1. - Photograph of the early tripod of Sternberg and Creager (1965) deployed from an anchored vessel. (See Table 1 for details.)

cal sense to several tidal cycles (several days) of operation because it required an anchored ship in a three-point mooring. A subsequent benthic tripod was constructed for remote use over more extended periods ( $\sim 30$ days) to depths up to $300 \mathrm{~m}$ (Sternberg et al., 1973). It contained instruments to measure near-bed currents, pressure fluctuations, bed configuration, the onset of sediment movement (time lapse camera), a beam transmissometer, and water/suspended sediment samplers (Fig. 2).

These early tripods were made possible by advances in marine instrumentation and techniques for deploying and recovering instrument systems from the seabed. These included acoustic releases, internally recording data loggers, and smaller, low powered instrumentation. As instrument capabilities continued to improve, new benthic systems were developed by numerous scientific groups around the world. The major increase of benthic measurement systems began in 1979 by scientists at the U.S.

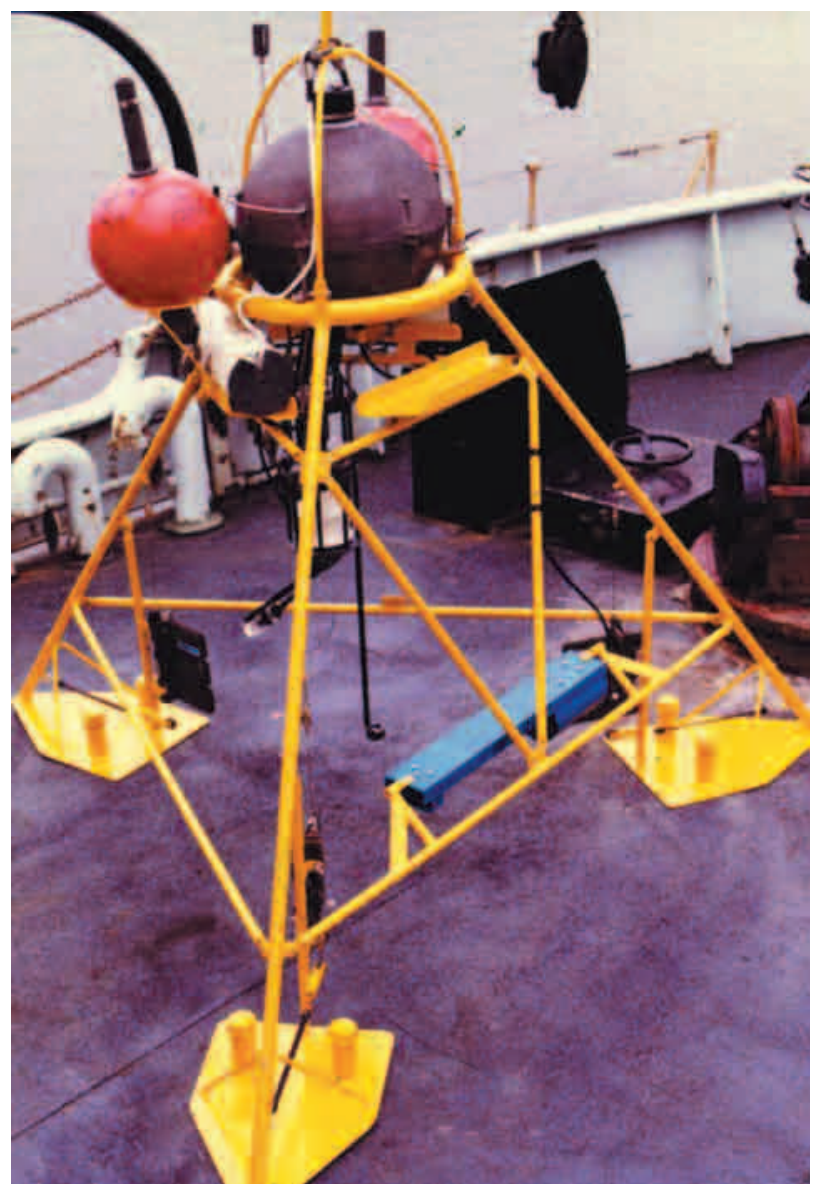

FIG. 2. - Photograph of the early tripod of Sternberg et al. (1973) designed for remote operation on the continental shelf. (See Table 1 for details.)

Geological Survey (Butman and Folger, 1979; Cacchione and Drake, 1979) followed by other scientific groups through the 1980s and continuing today. A brief summary of a few benthic tripods in use today is given in Table 1 . These benthic systems provide a range of capabilities and are operated by research groups from institutions in a number of countries. For example, some systems tend to monitor currents and sediment concentration at a single level over extended periods (e.g. USGS) or at two levels above the seabed (STRATAFORM tripod) while others have multiple sensors mounted at different elevations to evaluate velocity and suspended sediment concentration profiles. Although benthic tripods generally are constructed to operate at continental shelf depths (200-300 m), the BIOPROBE is designed for continental slope studies $(2500 \mathrm{~m})$ and the BASS tripod operates from shelf to deep-sea depths (Table 1).

The benthic tripod platform is basically a stable platform that can remain submerged for extended periods and contains release mechanisms, (e.g. 
TABLE 1. - Examples of tripod characteristics in terms of tripod, organization, reference, and elevations above the bed of current meters and suspended sediment concentration sensors or samplers. All tripods include pressure sensors and combinations of instruments as summarized in Table 2. The terms used include Savonius Rotor (rotor), electromagnetic current meter (EMCM), acoustic current meter (ACOUSTIC), transmissometer (XMISS), optical backscatterance sensor (OBS), acoustic backscatter sensor (ABS), acoustic doppler velocimeter (ADV), pulse coherent acoustic doppler profiler (PCADP).

\begin{tabular}{|c|c|c|c|c|}
\hline \multirow[t]{2}{*}{ Instrumented tripod } & \multirow[t]{2}{*}{ Organization } & \multirow[t]{2}{*}{ Reference } & \multicolumn{2}{|c|}{ Sensor elevations $(\mathrm{cm})$} \\
\hline & & & current meters & sed. sensors \\
\hline USGS & & & & \\
\hline Bottom tripod system & USGS, WHOI & Butman and Folger, 1979 & 100 rotor & 200 XMISS \\
\hline BASS & WHOI & Williams III, 1985 & $\begin{array}{l}\text { 40, 76, 135, 196, } 257 \\
496 \text { ACOUSTIC }\end{array}$ & $19,41,131,196 \mathrm{OBS}$ \\
\hline TRIPOD (New Zealand) & VIMS & Trembanis et al., 2004 & $\begin{array}{c}\text { 30, } 50 \text { ADV } \\
<150 \text { (3) EMCM }\end{array}$ & $\begin{array}{l}<150(4-5) \text { OBS } \\
<150(2) \text { sed. traps }\end{array}$ \\
\hline POD (STRATAFORM)* & VIMS & Wright et al., 1999 & $\begin{array}{l}\text { 10, 41, 71, 101, } \\
138 \text { EMCM }\end{array}$ & $15,42,71,104,131 \mathrm{OBS}$ \\
\hline TETRAPOD (U.K.) & $\begin{array}{l}\text { Bullard Labs, } \\
\text { Cambridge U. }\end{array}$ & Green et al., 1992 & $20,54,84,114$ EMCM & $\begin{array}{c}124,250 \text { XMISS } \\
36,68,98,128 \text { OBS } \\
120,3 \text { fre. ABS }\end{array}$ \\
\hline $\begin{array}{l}\text { TRIPOD } \\
\text { (STRATAFORM) }\end{array}$ & Univ. of Washington & $\begin{array}{l}\text { Ogston et al., } 2000 \\
\text { Sternberg and Nowell, } 1999\end{array}$ & 30, 100 EMCM & $30,100 \mathrm{OBS}$ \\
\hline $\begin{array}{l}\text { GEOPROBE } \\
\text { (STRATAFORM) }\end{array}$ & $\begin{array}{l}\text { USGS, } \\
\text { Menlo Park, CA }\end{array}$ & $\begin{array}{l}\text { Cacchione and Drake, } 1979 \\
\text { Cacchione et al., } 1999\end{array}$ & $21,54,90,123$ EMCM & $\begin{array}{c}29,97 \text { XMISS } \\
10,21,54,90,123, \text { OBS }\end{array}$ \\
\hline BIOPROBE & GEOMAR, Kiel & Thomsen et al., 1994 & $\begin{array}{l}15,20,65 \\
\text { thermistor flow meters }\end{array}$ & $\begin{array}{c}10,15,25,40 \text { water samplers } \\
40 \text { XMISS }\end{array}$ \\
\hline $\begin{array}{l}\text { TRIPOD } \\
\text { (EUROSTRATAFORM) }\end{array}$ & $\begin{array}{l}\text { Institut de Ciencias del Mar } \\
\text { (ICM), Barcelona }\end{array}$ & Puig (pers. comm.) & $\begin{array}{l}90 \text { EMCM } \\
125 \text { PCADP }\end{array}$ & $\begin{array}{c}10,20,30,50,100 \mathrm{OBS} \\
105,3 \text { fre. ABS }\end{array}$ \\
\hline
\end{tabular}

*example of tripod deployed at $60 \mathrm{~m}$ depth.

TABLE 2. - Examples of sensors used on benthic tripods.

\begin{tabular}{|c|c|}
\hline Instrument (acronym) & Comment \\
\hline \multicolumn{2}{|l|}{ Current Meters } \\
\hline electromagnetic (EMCM) & 2-D, $1 \mathrm{~Hz}$ \\
\hline acoustic travel time (BASS) & $3-\mathrm{D}, 1 \mathrm{~Hz}$ \\
\hline acoustic doppler velocimeter (ADV) & $3-\mathrm{D}, 25 \mathrm{~Hz}$ \\
\hline acoustic doppler profiler (ADCP) (PCADP) & 3-D, water column profiles \\
\hline \multicolumn{2}{|l|}{ Water Properties } \\
\hline CTD (CTD) & miniature/self-contained \\
\hline temperature $(\mathrm{T})$ & miniature/self-contained \\
\hline pressure sensor $(\mathrm{P})$ & small, low-power \\
\hline \multicolumn{2}{|l|}{ Seabed Imaging } \\
\hline acoustic altimeter (ALT) & seabed elevation changes $(\mathrm{cm})$ \\
\hline sector scanning sonar (SSS) & 2-m circular scan \\
\hline video/photographic camera & bed configuration/biota \\
\hline \multicolumn{2}{|l|}{ Particle Characteristics } \\
\hline beam transmissometer & susp. sed. concentration (low) \\
\hline optical backscatterance sensors (OBS) & susp. sed. concentration (high) \\
\hline floc camera (video, photographic) & susp. sed. floc size/settling velocity \\
\hline laser diffractometer (LISST) & susp. particle size \\
\hline acoustic backscattering system (ABS) & susp. sed. conc. profile \\
\hline sediment traps/pumping system & collect particles in situ \\
\hline
\end{tabular}

recovery floats with connecting ropes), and battery power. Sensor capabilities change continually. For example, the descriptions of some of the tripod systems in Table 1 are from the original publications cited (e.g. Sternberg et al., 1973; Butman and Folger, 1979); however, the present versions of these tripods and others such as those listed in Table 1 include numerous sensors. The range of sensors 
available for use on tripods is very broad as summarized in Table 2. Examples of the changes occurring in benthic tripods due to sensor capabilities are seen by comparison of the GEOPROBE system (Fig. 3; Table 1), the TRIPOD-New Zealand system (Fig. 4, Table 1), and the TRIPOD-EUROSTRATAFORM, or ICM tripod, which is the most recent tripod on the list (Fig. 5; Table 1). GEOPROBE contains individual current meter and suspended sediment sensors mounted at five distinct elevations on masts positioned within the tripod frame. This causes noticeable clutter and the legs present some flow disturbance to the sensors (while protecting the sensors) and makes observations of gradients from the five elevations. The VIMS-New Zealand tripod has the sensors swung outboard from the platform legs to minimize flow disturbance from the legs but exposes the sensors to possible damage. The ICM tripod uses acoustic sensors mounted within the upper frame that acoustically profile the water column below. As a result, there is no physical presence of current meters or suspended sediment concentration sensors within the measurement volume (the legs have a minimal profile to decrease flow disturbance). Velocity and suspended sediment concentration profiles are reconstructed from time-sequence "bins" virtually stacked from the seabed to the upper area of the tripod frame. The array of tripods used around the world is extensive and is always undergoing modification as sensors and scientific objectives evolve.

\section{TRIPOD APPLICATIONS}

The mix and individuality of tripod systems used within the marine sediment transport community (e.g. Table 1) provides a significant mechanism for interactive studies and comprehensive results. Indeed, the high cost of construction, deployment, and data analysis has promoted or strongly supported multi-investigator shelf studies. Benthic-tripod groups commonly deploy their instruments in coordinated arrays, share data, and/or interact in published results. Examples of several modes of tripod deployments are summarized in Table 3. This summary is not meant to be all-inclusive but to serve as an illustration of the breadth of benthic tripod work that is used to support comprehensive continental margin studies.

Inspection of Table 3 shows individual long-term deployments either with single tripods operating for

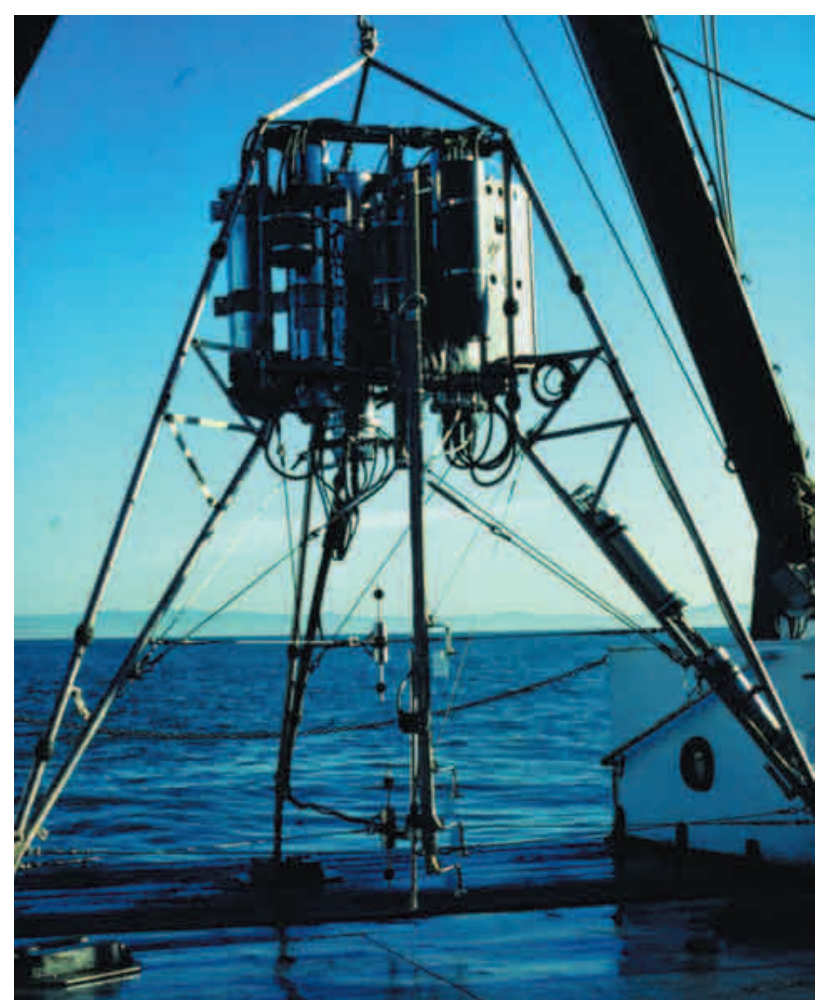

FIG. 3. - Photograph of the GEOPROBE tripod of Cacchione and Drake (1979) deployed on many continental shelves over the past $25 \mathrm{yr}$ (See Table 1 for details).

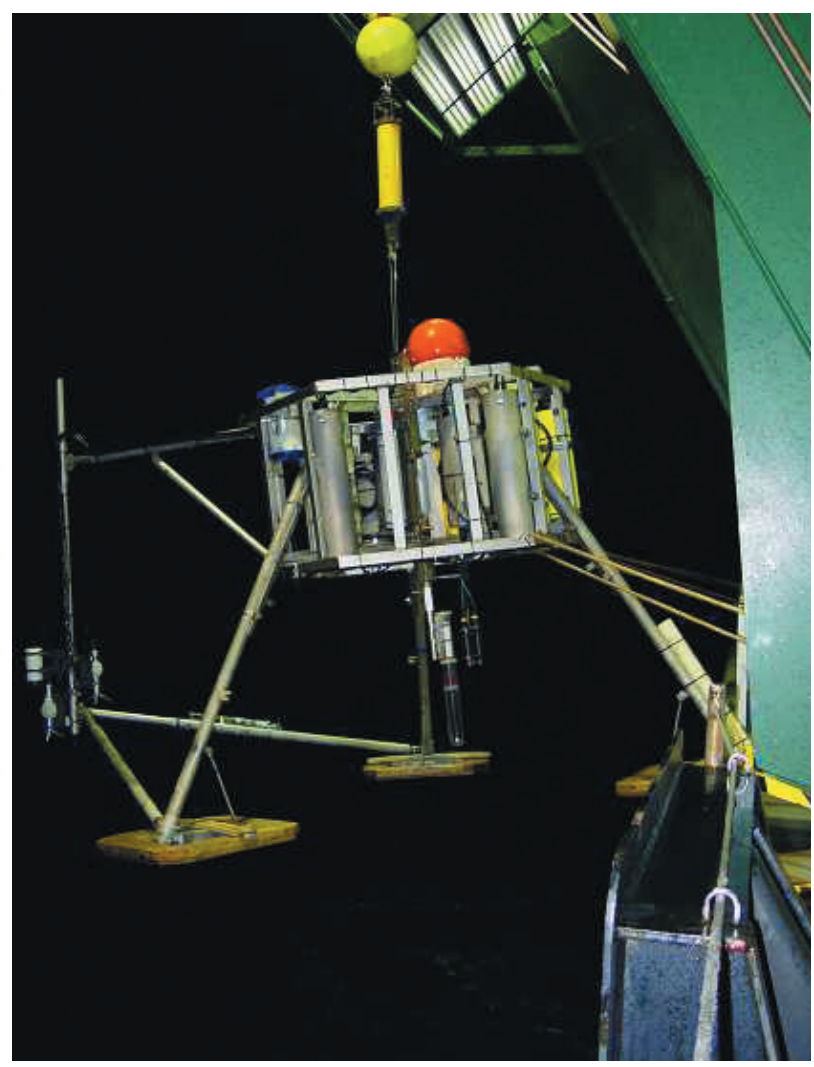

FIG. 4. - Photograph of the tripod designed at the Virginia Institute of Marine Sciences (Trembanis et al., 2004) and used on the New Zealand shelf (photograph courtesy of Bob Gammisch). (See Table 1 for details). 


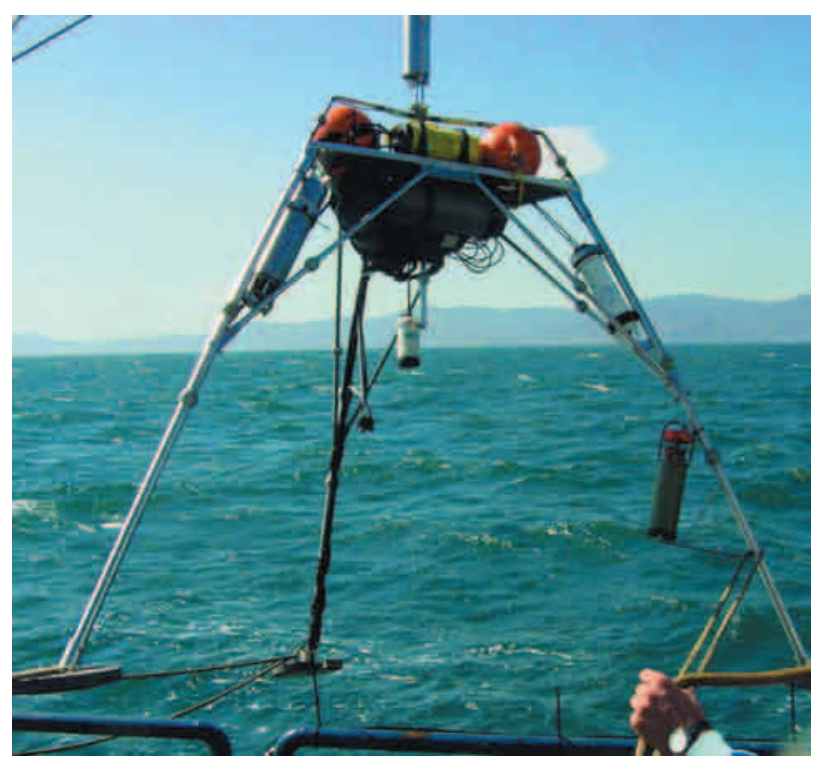

FIG. 5. - Photograph of the tripod designed by Puig, Palanques, and Guillén at the Institute de Ciencias del Mar, Barcelona, Spain, presently deployed off the east coast of Spain in cooperation with the EUROSTRATAFORM program (See Table 1 for details).

up to 12 mo (Barents Sea experiment), or similar tripods being substituted at regular intervals
(STRATAFORM) for a five-year period. Coordinated experiments from several research groups include, for example, across-shelf arrays to investigate sediment flux convergence (STRATAFORM, EUROSTRATAFORM), alongshelf arrays to investigate coast-parallel transport processes (STRATAFORM, EUROSTRATAFORM), and tripods deployed along with moored sediment traps, water sampling and water column profiling over the continental slope (OMEX I, II). In some cases across-shelf arrays are embedded within alongshelf arrays, all operating concurrently (EUROSTRATAFORM). The mix of instrument systems and scientific objectives has many permutations to suit the goals of the shelf experiment.

\section{DISCUSSION}

Investigations from benthic tripods over the past fifty years have had a major impact on our knowledge of fluid and sedimentary processes in coastal seas. In general, studies have followed two distinct

TABLE 3. - Limited examples of a range of tripod studies and cooperative studies to monitor and study shelf sedimentary processes. Under each study is listed the geographic region and funding agency.

\begin{tabular}{|c|c|c|c|c|c|}
\hline Study & Years & Objective & Array characteristics & Comments & General reference \\
\hline $\begin{array}{l}\text { Barents Sea } \\
\text { Experiment } \\
(\text { ONR })\end{array}$ & 1991-1992 & $\begin{array}{l}\text { Sed. transport under } \\
\text { a seasonal ice cover }\end{array}$ & $\begin{array}{l}\text { Two tripods (Melbourne, } \\
\text { Aus.) deployed under } \\
\text { seasonal ice field } \\
\sim 200 \mathrm{~m} \text { depth }\end{array}$ & $\begin{array}{l}\text { Continuous data } \\
\text { collection over } \\
12 \text {-mo period }\end{array}$ & Sternberg et al., 2001 \\
\hline $\begin{array}{l}\text { OMEX I, II } \\
\text { N. Gulf of Biscay } \\
\text { New Iberian Margin } \\
\text { (EU) }\end{array}$ & 1993-1995 & $\begin{array}{l}\text { Across-margin flux } \\
\text { carbon, lithogenic } \\
\text { material }\end{array}$ & $\begin{array}{l}\text { (e.g., OMEX I) } \\
\text { Two landers, sediment } \\
\text { traps, bottom sampling, } \\
\text { water columnprofiles, } \\
\text { CTD, beam attenuation }\end{array}$ & $\begin{array}{l}\text { (e.g., OMEX I) } \\
\text { Across-margin } \\
\text { observations } 300-4000 \mathrm{~m} \\
\text { depth, } 2 \text { tripods at } \\
1296-2100 \mathrm{~m} \text { sequentially } \\
\text { deployed for up to } 13 \text { mo }\end{array}$ & $\begin{array}{l}\text { Wollast et al., 2001; } \\
\text { van Weering and } \\
\text { McCave, } 2002\end{array}$ \\
\hline $\begin{array}{l}\text { STRATAFORM } \\
\text { Eel River shelf } \\
\text { (ONR) }\end{array}$ & $1995-2000$ & $\begin{array}{l}\text { Long term sed. } \\
\text { transport on a mid } \\
\text {-shelf mud deposit }\end{array}$ & $\begin{array}{l}\text { UW tripod at } 60 \mathrm{~m} \text { depth } \\
\text { (mid-shelf mud) }\end{array}$ & $\begin{array}{l}\text { Two similar UW tripods } \\
\text { cycled at shelf location } \\
\text { every } 4 \text { mo, continuous } \\
\text { data stream over } 5 \text { yr }\end{array}$ & $\begin{array}{l}\text { Ogston and Sternberg, } \\
\text { 1999; Ogston et al., } \\
\text { 2004; Guerra, } 2004\end{array}$ \\
\hline $\begin{array}{l}\text { Coordinated } \\
\text { Deployments } \\
\text { STRATAFORM }\end{array}$ & 1996 & $\begin{array}{l}\text { Across-shelf sediment } \\
\text { flux convergence }\end{array}$ & $\begin{array}{l}\text { Three-tripod cross-shelf } \\
\text { array for two winter } \\
\text { months }\end{array}$ & $\begin{array}{l}\text { Two VIMS tripods } \\
(60,70 \mathrm{~m}), \text { GEOPROBE } \\
(50 \mathrm{~m})\end{array}$ & Wright et al., 1999 \\
\hline$(\mathrm{ONR})$ & 1996-1997 & $\begin{array}{l}\text { Alongshelf sediment } \\
\text { flux convergence }\end{array}$ & $\begin{array}{l}\text { Three-tripod alongshelf } \\
\text { array on } 60 \text { m isobath, } \\
\text { Nov. } 1996 \text { - Jan. } 1997\end{array}$ & $\begin{array}{l}\text { VIMS Pod }(60 \mathrm{~m}) \\
\text { GEOPROBE }(60 \mathrm{~m}) \\
\text { UW tripod }(60 \mathrm{~m})\end{array}$ & Ogston et al., 2000 \\
\hline $\begin{array}{l}\text { EUROSTRATAFORM } \\
\text { (PASTA) } \\
\text { Western Adriatic Shel }\end{array}$ & $\begin{array}{l}2001-2003 \\
\text { lf }\end{array}$ & $\begin{array}{l}\text { Alongshelf } \\
\text { sediment flux }\end{array}$ & $\begin{array}{l}\text { Six tripods on } 12 \mathrm{~m} \\
\text { isobath from Po-Pescara } \\
\text { rivers, Italian shelf }\end{array}$ & $\begin{array}{l}\text { UW (2 tripod, } 12 \mathrm{~m}) \\
\text { WHOI (2 tripod, } 12,20 \mathrm{~m}) \\
\text { USGS-WHOI }(2 \text { tripod, } \\
9 \text { and } 20 \mathrm{~m})\end{array}$ & In process \\
\hline (ONR, EU) & $2002-2003$ & $\begin{array}{l}\text { Across-shelf sediment } \\
\text { flux }\end{array}$ & $\begin{array}{l}\text { Two tripods, one mooring, } \\
\text { off Pescara River }\end{array}$ & $\begin{array}{l}\text { UW tripod }(12 \mathrm{~m}) \\
\text { ICM tripod }(20 \mathrm{~m}) \\
\text { ICM mooring }(50 \mathrm{~m}) \\
\text { Winter deployment }\end{array}$ & $\begin{array}{l}\text { Puig et al., } 2004 \\
\text { (submitted) }\end{array}$ \\
\hline
\end{tabular}


pathways and are contributing to a third. These include (1) validation and application of boundarylayer and sediment transport theory in the sea; (2) documentation and identification of the range of physical processes and associated sediment transport active on continental shelves; and (3) data input for development and evaluation of numerical models of shelf circulation and sedimentology.

\section{Boundary layer processes}

When benthic tripods were initially developed and deployed, the objectives were to measure velocity profiles within 1-2 $\mathrm{m}$ of the seabed and to determine if they followed the classic "law of the wall" form. It was important, as an initial step, to explore whether marine boundary layer flows followed theoretical forms developed in the 1920s and 1930s. Prior documentation of boundary-layer flows and sediment transport only had been carried out in flumes and rivers (e.g. Gilbert, 1914; Nikuradze, 1933; Hjulstrom, 1939; White, 1940; Guy et al., 1966). The verification of the log-profile in the sea provided a way to evaluate constants and parameters used to understand such physical concepts of boundary shear stress, drag coefficients, threshold of grain motion, and turbulent exchange of particulates and chemical species across the sediment-water interface.

The results of early field investigations in the sea were very promising. Log profiles were observed in marine boundary layer tidal flows and parameters such as the boundary roughness length (Sverdrup et al., 1942; Lesser, 1951; Dyer, 1970), and frictional drag coefficients over various boundary types (e.g. Sternberg, 1968, 1976) were determined. Additionally, sediment transport characteristics were evaluated in terms of the threshold of grain motion (Sternberg, 1971; Sternberg and Larsen, 1975) and bedload transport (Kachel and Sternberg, 1971; Sternberg, 1972).

Recent benthic tripod observations using the latest generation of instruments has continued to advance our knowledge of boundary-layer flows under a wide range of marine conditions. This includes, for example, evaluation of suspended sediment concentration profiles (e.g. Kineke and Sternberg, 1989; Guillén et $a l .$, 2002); influence of high concentrations of suspended sediment on boundary layer flows (Friederichs and Wright, 1997; Friederichs et al., 2000; Wright et al., 2001), fluid mud formation on the continental shelf (Cacchione et al., 1995; Kineke and Sternberg, 1995; Kineke et al., 1996; Sternberg et al.,
1996; Ogston et al., 2000; Traykovski et al., 2000), biological mediation of threshold of grain motion (Nowell et al., 1981; Wright et al., 1997) and boundary layer processes (Drake et al., 1992). Studies of boundary layer flows and associated sediment transport dynamics represent the means by which marine scientists have improved our ability to link physical process to sediment response, predict the impact of various physical factors on coastal seas (e.g. crossshelf transport, patterns of erosion and deposition, development of event stratigraphy) and provide a conceptual and theoretical base for numerical models.

\section{Physical process identification}

The first tripods deployed for extended periods were designed to remain submerged for periods of approximately one month and to be redeployed as possible over winter months to document nearbed conditions under storm conditions when ship operations were not possible. The objectives of these early studies were expressed by a series of questions:

- When does sediment move?

- What are the directions of transport?

- How much is transported?

- What physical processes cause sediment movement?

- What conditions control the distribution of modern shelf sedimentary deposits?

Beginning in the 1970s, the above objectives were addressed with benthic tripod deployments on various continental shelves of the United States (e.g. Smith and Hopkins, 1972; Sternberg and McManus, 1972; McClennen, 1973; Gordon, 1975; Sternberg and Larsen, 1976; Sternberg et al., 1977; Butman et al., 1979; Vincent et al., 1981) and continuing into the present (e.g. in European waters, Green et al., 1995; Palanques et al., 2002). Results of these studies highlighted the importance of waves, tidal flows, currents, and seasonal storm events in forcing shelf sediment transport and addressed a number of these original questions on numerous continental shelves (e.g. summarized in Sternberg, 1986; Sherwood et al., 1994; Sternberg and Nowell, 1999).

In more recent decades the availability of instruments (Table 2) and capability for extended deployments has led to the documentation and identification of numerous other processes that contribute and at times dominate shelf sediment transport. A summary of these processes is given in Table 4 along with some example references. A noteworthy aspect of the list in Table 4 is its potential impact on all 
TABLE 4. - Shelf sediment transport: processes of importance based on concepts of the 1970s and the present. A few example references are also given for each process.

\begin{tabular}{|c|c|c|}
\hline Period & Process & Example references \\
\hline $1970 \mathrm{~s}$ & $\begin{array}{l}\text { Waves } \\
\text { Tides } \\
\text { Currents } \\
\text { Seasonal events }\end{array}$ & $\begin{array}{l}\text { Sternberg and Larsen, } 1976 \\
\text { Butman et al., } 1979 \\
\text { Sternberg and McManus, 1972; Butman et al., } 1979 \\
\text { Sternberg et al., } 1977\end{array}$ \\
\hline Present & $\begin{array}{l}\text { Waves } \\
\text { Tides } \\
\text { Currents } \\
\text { Wind band (dy-wks) } \\
\text { Mesoscale band (wk-mos) } \\
\text { Plume effects: } \\
\quad \text { buoyancy } \\
\quad \text { divergent sediment delivery } \\
\text { Frontal dynamics } \\
\text { Internal waves } \\
\text { Mass movements } \\
\quad \text { fluid mud } \\
\quad \text { inner shelf fluidization } \\
\text { Source/sink connections } \\
\text { (e.g. river discharge; submarine canyons) }\end{array}$ & $\begin{array}{l}\text { Wright et al., 1986; Geyer et al., 2000; Hill et al., } 2000 \\
\text { Kineke et al., 2000 } \\
\text { Kineke et al., 1996; Ogston et al., 2000 } \\
\text { Gardner, 1989; Cacchione et al., 2000; Puig et al., 2001; McPhee-Shaw et al., } 2004 \\
\text { Cacchione et al., 1995; Kineke and Sternberg, 1995; Mulder and Syvitski, 1995; } \\
\text { Kineke et al., 1996; Traykovski et al., 2000; Wright et al., } 2002 \\
\text { Fredericks and Wright, in press } \\
\text { Baker and Hickey, 1986; Milliman and Syvitski, 1992; Wheatcroft et al., 1997; } \\
\text { Wheatcroft and Borgeld, 2000; Mullenbach and Nittrouer, 2000; Puig et al., 2003 }\end{array}$ \\
\hline
\end{tabular}

facets of the continental shelf marine environment, not just sedimentology. As other oceanographic disciplines participating in large interdisciplinary shelf studies have gained the ability to visualize, document, and measure the range of processes at work, new levels of understanding of physical, chemical, and biological processes have emerged. One example of the interdisciplinary potential of these studies is illustrated in the documentation of fluid mud formed on the Amazon shelf (nearbed sediment suspensions $>10 \mathrm{~g} / \mathrm{l}$ ). The observed fluid mud, once identified, mapped, and sampled, was found to strongly influence shelf sediment transport and depositional patterns (Faas, 1986; Kineke and Sternberg, 1989; Cacchione et al., 1995; Kineke et al., 1995; Kuehl et al., 1996). Fluid mud also was found to significantly influence tidal sediment dynamics in the river mouth (Jaeger and Nittrouer, 1995), mud flat sediment storage (Allison et al., 1995), tide propagation on the open shelf (Beardsley et al., 1995), tide-induced mixing (Geyer, 1995), chemical signatures and budgets (Moore et al., 1996), sediment remineralization, recycling, and storage (Aller et al., 1996), and the benthic community structure (Aller and Stupakoff, 1996). So these broadly based and extensive shelf studies have significant interdisciplinary implications.

\section{Numerical modeling}

Because benthic studies document such a wide range of oceanic conditions, they have been influ- ential in both development and validation of time dependent, numerical models of shelf circulation and sediment transport. Examples of models include 1D resuspension models of Wiberg and Smith (1983), Wiberg et al. (1994), and Cacchione et al. (1999), 2D, time-dependent circulation models incorporating wind stress, river discharge, and bathymetry reported by Pullen and Allen $(2000,2001)$ and 2D, time-dependent models incorporating the advection-diffusion equation to calculate suspended sediment concentration, net erosion, deposition and seabed modification during resuspension events (Harris and Wiberg, 2001, 2002). Considering the elapsed time from field identification and documentation of various processes (e.g. Table 4) to the incorporation of new concepts with appropriate physics into numerical models, it is not surprising that major model development lags field observation. Model development, therefore, tends to proceed in steps. The extensive comprehensive models of Harris and Wiberg $(2001,2002)$ do not yet include, for example, the physics of fluid mud formation and its potential role in cross-margin transport. The physics of fluid mud, however, has been and is being modeled from observations made off the Amazon shelf (Trowbridge and Kineke, 1994), and the northern California shelf (Scully et al., 2002). Presumably these process-specific models will eventually be incorporated into shelf-wide models as well as other processes such as those summarized in Table 4. 


\section{FUTURE IMPACTS}

Benthic tripod studies have contributed significantly to our knowledge of shelf sediment transport, and the data base from these studies has been important as shelf scientists expand their efforts from field observation to numerical modeling and associated predictive capabilities. To the extent that the range and mix of physical forcing mechanisms that drive sediment transport is still being discovered, benthic tripods should continue to play a role in shelf studies into the foreseeable future.

An additional aspect of future marine science is the consideration of ocean observatories for carrying out studies over decades rather than years. Examples include the Longterm Ecosystem Observatory located on the New Jersey inner shelf (LEO-15) operated by Rutgers University for over a decade. LEO-15 is a cabled network on the seabed that transmits to shore, in real time, visual images and measurements of temperature, currents, and pressure. Another cabled network in the planning stage is NEPTUNE which will be a fiber-optic/power network of distributed sensors on the scale of an oceanic plate off the west coast of the United States and Canada (Delaney et al., 2001). Other considerations of long-range observatories have been made by the National Oceanic and Atmospheric Administration of the U.S. (Jahnke et al., 2003), the Ocean Observatories Initiative (OOI) of NSF, and the Ocean Research Interactive Observatory Networks (ORION) program under the auspices of the U.S. National Science Foundation (NSF), Joint Oceanographic Institutions (JOI), and the Consortium for Oceanographic Research and Education (CORE). ORION is an overarching program that encompasses OOI and NEPTUNE (e.g. see http://orionprogram.org) and also includes a wide range of ocean observatory concepts. As future initiatives and plans for seabed observatories are being considered, the instrumental capabilities developed and used in benthic tripod investigations are providing a base of knowledge and experience for these evolving initiatives. An example of this instrument crossover is seen in the Science White Paper \#1, "Cross-margin particulate flux studies associated with NEPTUNE" (C.A. Nittrouer, 2004) which incorporates many of the sensors used on present-day benthic tripods.

\section{CONCLUSIONS}

The development of the benthic tripod as a stable platform on the seabed has evolved over 50 years in response to advances in deployment/retrieval capabilities and individual sensor technology. Although the basic tripod concept has not changed substantially from the early years, the sensors mounted on these platforms are continually changing, reflecting individualized study goals and major advances in instrument development.

The scientific results from benthic tripod deployments have been far-reaching. These include the understanding of marine boundary-layer flows and resulting sediment transport; identification of a wide range of physical processes which contribute to shelf and slope sedimentology and often play a dominant role; and the collection of a necessary data base for predictive model development and verification. The breadth of new knowledge and concepts resulting from benthic tripod studies has had a major influence on our understanding of the coastal ocean. These findings also have application to all of the oceanographic disciplines, not just the physical and sedimentological aspects. It is expected that use of benthic tripods has relevance into the future and will continue. Additionally, the technical aspects of these instrumentation systems will provide a base of experience as the scientific community considers new initiatives for the future, such as expansion into long-term submarine observatories.

\section{REFERENCES}

Aller, J.Y. and I. Stupakoff. - 1996. The distribution and seasonal characteristics of benthic communities on the Amazon shelf as indicators of physical processes. Cont. Shelf Res., 16: 717-751.

Aller, R.C., N.E. Blair, Q. Xia and P.D. Rude. - 1996. Remineralization rates, recycling, and storage of carbon in Amazon shelf sediments. Cont. Shelf Res., 16: 753-786.

Allison, M.A., C.A. Nittrouer and G.C. Kineke. - 1995. Seasonal sediment storage on mudflats adjacent to the Amazon River. Mar. Geol., 125: 303-328.

Baker, E.T. and B.M. Hickey. - 1986. Contemporary sedimentation processes in and around an active west coast submarine canyon. Mar. Geol., 71: 15-34.

Beardsley, R.C., J. Candela, R. Limeburner, W.R. Geyer, S.J. Lentz, B.M. Castro, D. Cacchione and N. Carneiro. - 1995. The M2 tide on the Amazon shelf. J. Geophys. Res., 100: 2283-2319.

Bowden, D.F. and L.A. Fairbairn. - 1952. A determination of the frictional forces in a tidal current. Proc. Roy. Soc. London A, 214: 371-392.

Bowden, D.F., L.A. Fairbairn and P. Hughes. - 1959. The distribution of shearing stresses in a tidal current. Geophys. J., 2: 288-305.

Butman, B. and D.W. Folger. - 1979. An instrument system for long-term sediment transport studies on the continental shelf. $J$. Geophys. Res., 84: 1215-1220.

Butman, B., M. Noble and D.W. Folger. - 1979. Long-term observations of bottom current and bottom sediment move- 
ment on the mid-Atlantic continental shelf. J. Geophys. Res., 84: 1187-1205.

Cacchione, D.A. and D.E. Drake. - 1979. A new instrument system to investigate sediment dynamics on continental shelves. Mar. Geol., 30: 299-312.

Cacchione, D.A., D.E. Drake, R.W. Kayen, R.W. Sternberg, G.C. Kineke and G.B. Tate. - 1995. Measurements in the bottom boundary layer on the Amazon subaqueous delta. Mar. Geol., 125: 235-257.

Cacchione, D.A., L.F. Pratson and A.S. Ogston. - 2000. The shaping of continental slopes by internal tides. Science, 296: 724727.

Cacchione, D.A., P.L. Wiberg, J. Lynch, J. Irish and P. Traykovski. - 1999. Estimates of suspended-sediment flux and bedform activity on the inner portion of the Eel continental shelf. Mar. Geol., 154: 83-97.

Charnock, H. - 1959. Tidal friction from currents near the sea bed. Geophys. J., 2: 215-221.

Collins, C.A., H.C. Creech and J.G. Patullo. - 1966. A compilation of observations from moored current meters and thermographs. Vol. I: Oregon continental shelf, July 1965 - February 1966. Oregon State University, Department of Oceanography, Data Report No. 23.

Delaney, J.R., G.R. Heath, A. Chave, H. Kirkham, B. Howe, W. Wilcock, P. Beauchamp and A. Maffei. - 2001. Neptune: realtime, long-term ocean and earth studies at the scale of a tectonic plate. Oceans 2001 Conference, 29-31 October 2001, Biloxi, MS.

Drake, D.E., D.A. Cacchione and W.D. Grant. - 1992. Shear stress and bed roughness estimates for combined wave and current flows over a rippled bed. J. Geophys. Res., 97: 2319-2326.

Duxbury, A.C. -1956 . The velocity profiles and stresses above the sea floor in Agate Passage and San Juan Channel. M.S. thesis, University of Washington, Seattle, WA. 78 pp.

Dyer, K.R. - 1970. Current velocity profiles in a tidal channel. Geophys. J. R. Astr. Soc., 22: 153-161.

Faas, R.W. (1986) Mass-physical and geotechnical properties of surficial sediments and dense nearbed sediment suspensions on the Amazon continental shelf. Cont. Shelf Res., 6: 189-208.

Friedrichs, C.T. and L.D. Wright. - 1997. Sensitivity of bottom stress and bottom roughness estimates to density stratification, Eckernförde Bay, Southern Baltic Sea. J. Geophys. Res., 102: 5721-5732.

Friedrichs, C.T. and L.D. Wright. - 2004. Analytical model for equilibrium shelf profiles near river mouths. Virginia Institute of Marine Sciences, in press.

Friedrichs, C.T., L.D. Wright, D.A. Hepworth and S.C. Kim. 2000. Bottom boundary layer processes associated with fine sediment accumulation in coastal seas and bays. Cont. Shelf Res., 20: 807-841.

Gardner, W. - 1989. Periodic resuspension in Baltimore Canyon by focusing of internal waves. J. Geophys. Res., 94, 18185-18194.

Geyer, W.R. - 1995. Tide-induced mixing in the Amazon frontal zone. J. Geophys. Res., 100: 2341-2353.

Geyer. W.R., P. Hill, T. Milligan and P. Traykovski. - 2000. The structure of the Eel River plume during floods. Cont. Shelf Res., 20: 2067-2093.

Gilbert, K.G. - 1914. The transportation of debris by running water. U.S. Geol. Surv. Prof., Paper 86, Washington, D.C.

Gordon, C.M. - 1975. Sediment entrainment and suspension in a tidal flow. Mar. Geol., 18: M57-M64.

Grace, S.F. - 1937. Friction in the tidal currents of the English Channel. Mon. Not. R. Astr. Soc. Geophys. Suppl. 4: 133-142.

Green, M.O., N.D. Pearson, M.R. Thomas, C.D. Rees, J.M. Rees and T.R.E. Owen. - 1992. Design of a data logger and instrument-mounting platform for seabed sediment-transport research. Cont. Shelf Res., 12: 543-562.

Green, M.O., C.E. Vincent, I.N. McCave, R.R. Dickson, J.M. Rees and N.D. Pearson. - 1995. Storm sediment transport: observations from the British North Sea shelf. Cont. Shelf Res., 15: 889-912.

Guerra, J.V. - 2004. Interannual variability of nearbed sediment flux and associated physical processes on the Eel River shelf, northern California, USA. Ph.D. Dissertation, University of Washington, Seattle, WA. 114 pp.

Guillén, J., J.A. Jiménez, A. Palanques, V. Gracia, P. Puig and A. Sánchez-Arcilla. - 2002. Sediment resuspension across a microtidal, low-energy inner shelf. Cont. Shelf Res., 22: 305-325.
Guy, H.R., D.B. Simons and E.V. Richardson. - 1966. Summary of alluvial channel data from flume experiments, 1956-1961. U.S. Geol. Surv. Prof., Paper 462-I, Washington, D.C.

Harris, C.K. and P.L. Wiberg. - 2001. A two-dimensional, timedependent model of suspended sediment transport and bed reworking for continental shelves. Comp. and Geosci., 27: 675690.

Harris, C.K. and P.L. Wiberg. - 2002. A cross-shelf sediment transport: interactions between suspended sediment and bed sediment. J. Geophys. Res., 107: 8-1 to 8-12.

Hill, P.S., T.G. Milligan and W.R. Geyer. - 2000. Controls on effective settling velocity of suspended sediment in the Eel River flood plume. Cont. Shelf Res., 20: 2095-2111.

Hjulstrom, F. - 1939. Transportation of detritus by moving water. In: P.D. Trask (ed.), Recent Marine Sediments, pp. 5-31. American Association of Petroleum Geology, Tulsa, OK.

Hopkins. T.S. - 1971. On the circulation ove the continental shelf off Washington. Ph.D. Dissertation, University of Washington, Seattle, WA. 204 pp.

Jaeger, J.M. and C.A. Nittrouer. - 1995. Tidal controls on the formation of fine-scale sedimentary strata near the Amazon river mouth. Mar. Geol., 125: 259-281.

Jahnke, R., J. Bane, A. Barnard, J. Barth, F. Chavez, H. Dam, E. Dever, P. DiGiacomo, J. Edson, R. Geyer, S. Glenn, K. Johnson, M. Moline, J. O’Donnell, J. Oltman-Shay, O. Persson, O. Schofield, H. Sosik and E. Terrill. - 2003. Coastal observatory research arrays: a framework for implementation planning. Report on the CoOP CORA Workshop, 12-13 November 2003, Chicago, IL. Skidaway Institute of Oceanography Technical Report TR-03-01. 77 pp.

Jiménez, J.A., J. Guillén, V. Gracia, A. Palanques, M.A. García, A. Sánchez-Arcilla, P. Puig, J. Puigdefábregas and G. Rodríguez. 1999. Water and sediment fluxes on the Ebro Delta shoreface: on the role of low frequency currents. Mar. Geol., 157: 219-239.

Kachel, N.B. and R.W. Sternberg. - 1971. Transport of bedload as ripples during an ebb current. Mar. Geol., 19: 229-244.

Kineke, G.C. and R.W. Sternberg. - 1989. The effect of particle settling velocity on computed suspended sediment concentration profiles. Mar. Geol., 90: 159-174.

Kineke, G.C. and R.W. Sternberg. - 1995. Distribution of fluid muds on the Amazon continental shelf. Mar. Geol., 124: 193-233.

Kineke, G.C., R.W. Sternberg, J.H. Trowbridge and W.R. Geyer. 1996. Fluid-mud processes on the Amazon continental shelf. Cont. Shelf Res., 16: 667-696.

Kineke, G.C., K.J. Woolfe, S.A. Kuehl, J. Milliman, T.M. Dellapenna and R.G. Purdon. - 2000. Sediment export from the Sepik River, Papua New Guinea: evidence for a divergent sediment plume. Cont. Shelf Res., 20: 2239-2266.

Kuehl, S.A., C.A. Nittrouer, M.A. Allison, L. Ercilio, C. Faria, D.A. Dukat, J.M. Jaeger, T.D. Pacioni, A.G. Figueiredo and E.C. Underkoffler. - 1996. Sediment deposition, accumulation, and seabed dynamics in an energetic fine-grained coastal environment. Cont. Shelf Res., 16: 787-815.

Lesser, R.M. - 1951. Some observations of the velocity profile near the sea floor. Trans. Am. Geophys. Union, 37(2): 207-211.

McClennen , C.E. - 1973. New Jersey continental shelf near-bottom current meter records and recent sediment activity. J. Sed. Petrol., 43: 371-380.

McPhee-Shaw, E.E, R.W. Sternberg, B. Mullenbach and A.S Ogston. - 2004. Observations of intermediate nepheloid layers on the Northern California continental margin. Cont. Shelf Res., 24 , in press.

Milliman, J.D. and J.P.M. Syvitski. - 1992. Geomorphic/tectonic control of sediment discharge to the ocean: the importance of small mountainous rivers. J. Geol., 100: 525-544.

Moore, W.S., D.J. DeMaster, J.M. Smoak, B.A. McKee and P.W. Swarzenski. - 1996. Radionuclide tracers of sedimentwater interactions on the Amazon shelf. Cont. Shelf Res., 16: 645-665

Mosby, H. - 1947. Experiments on turbulence and friction near the bottom of the sea. Bergens Museums Årbok 1946/47. Nagturvitenskapelig rekke Nr. 3.

Mosby, H. - 1949. Experiments on bottom friction. Universitetet $i$ Bergen Årbok 1949. Nagturvitenskapelig rekke Nr. 10.

Mulder, T. and J.P.M. Syvitski. - 1995. Turbidity currents generated at river mouths during exceptional discharges to the world oceans. J. Geol., 103: 285-299. 
Mullenbach, B.L. and C.A. Nittrouer. - 2000. Rapid deposition of fluvial sediment in the Eel Canyon, northern California. Cont. Shelf Res., 20: 2191-2212.

Nikuradse, J. - 1933. Stromungsgesetze in rauhen Rohren: VDIForschungschaft 361, Beilage zu Forschung auf dem Gebiete des Ingenieurwesens Ausgabe B Band 4.

Nittrouer, C.A. (chair) - 2004. Neptune Science White Paper \#1: Cross-margin particulate flux studies associated with Neptune. $<$ http://www.neptune.washington.edu/science_wrkgp/ Cross-Margin.html>

Nowell, A.R.M., P.A. Jumars and J.E. Eckman. - 1981. Effects of biological activity on the entrainment of marine sediments. Mar. Geol., 42: 133-153.

Ogston, A.S., D.A. Cacchione, R.W. Sternberg and G.C. Kineke. 2000. Observations of storm and river flood-driven sediment transport on the northern California continental shelf. Cont. Shelf Res., 20: 2141-2162.

Ogston, A.S., J.V. Guerra and R.W. Sternberg. - 2004. Interannual variability of nearbed sediment flux on the Eel River shelf, northern California. Cont. Shelf Res., 24: 117-136.

Ogston, A.S. and R.W. Sternberg. - 1999. Sediment-transport events on the northern California continental shelf. Mar. Geol. 154: 69-82.

Palanques, A., P. Puig, J. Guillén, J. Jiménez, V. Gracia, A. SánchezArcilla and O. Madsen. - 2002. Near-bottom suspended sediment fluxes on the microtidal low-energy Ebro continental shelf (NW Mediterranean). Cont. Shelf Res., 22: 285-303.

Puig., P., A.S. Ogston, J. Guillén, A. Fain and A. Palanques. - 2004 Sediment transport processes from the topset to the foreset of a crenulated clinoform (Adriatic Sea). Cont. Shelf Res. (in press).

Puig, P., A.S. Ogston, B.I. Mullenbach, C.A. Nittrouer and R.W. Sternberg. - 2003. Shelf-to-canyon sediment transport processes on the Eel continental margin (northern California). Mar. Geol., 193: 129-149.

Puig, P., A. Palanques and J. Guillén. - 2001. Near-bottom suspended sediment variability caused by storms and near-inertial internal waves on the Ebro mid continental shelf (NW Mediterranean). Mar. Geol., 178: 81-93.

Pullen, J.D. and J.S. Allen. - 2000. Modeling studies of the coastal circulation off Northern California: Shelf response to a major Eel River flood event. Cont. Shelf Res., 20: 2213-2238.

Pullen, J.D. and J.S. Allen. - 2001. Modeling studies of the coastal circulation off Northern California: statistics and patterns of wintertime flow. J. Geophys. Res., 106, 26959-26984.

Scully, M.E., C.T. Friedrichs and L.D. Wright. - 2002. Application of an analytical model of critically stratified gravity-driven sediment transport and deposition to observations from the Eel River continental shelf, Northern California. Cont. Shelf Res., 22: 1951-1974.

Sherwood, C.R., B. Butman, D.A. Cacchione, D.E. Drake, T.F. Gross, R.W. Sternberg, P.L. Wiberg and A.J. Williams III. 1994. Sediment-transport events on the northern California continental shelf during the 1990-1991 STRESS experiment. Cont. Shelf Res., 14: 1063-1099.

Smith, J.D. and T.S. Hopkins. - 1972. Sediment transport on the continental shelf off Washington and Oregon in light of recent current measurements. In: D.J.P. Swift, D.B. Duane and O.H. Pilkey (eds.), Shelf Sediment Transport, pp. 143-180. Dowden, Hutchinson and Ross, Stroudsburg, PA.

Sternberg, R.W. - 1968. Friction factors in tidal channels with differing bed roughness. Mar. Geol., 6: 243-260.

Sternberg, R.W. - 1971. Measurements of incipient motion of sediment particles in the marine environment. Mar. Geol., 10: 113-119.

Sternberg, R.W. - 1972. Predicting initial motion and bedload transport of sediment particles in the shallow marine environment. In: Swift, Duane and Pilkey (eds.), Shelf Sediment Transport, pp. 61-82. Dowden, Hutchinson and Ross, Inc., Stroudsburg, PA.

Sternberg, R.W. - 1976. Measurements of boundary-layer flow and boundary roughness over Campeche Bank, Yucatan. Mar. Geol., 20: M25-M31.

Sternberg, R.W. - 1986. Transport and accumulation of riverderived sediment on the Washington continental shelf, USA. $J$ Geol. Soc. London, 143: 945-956.

Sternberg, R.W., K. Aagaard, D. Cacchione, R.A. Wheatcroft, R.A. Beach, A.T. Roach and M.A.H. Marsden. - 2001. Long-term near-bed observations of velocity and hydrographic properties in the northwest Barents Sea with implications for sediment transport. Cont. Shelf Res., 21: 509-529.

Sternberg, R.W., D.A. Cacchione, B. Paulson, G.C. Kineke and D.E. Drake. - 1996. Observations of sediment transport on the Amazon subaqueous delta. Cont. Shelf Res., 16: 697-715.

Sternberg, R.W. and J.S. Creager. - 1965. An instrument system to measure boundary-layer conditions at the sea floor. Mar. Geol., 3: $475-482$.

Sternberg, R.W., J.S. Creager. W. Glassley and J. Johnson (eds.). 1977. Aquatic disposal field investigations, Columbia River disposal site, Oregon. Appendix A: investigation of the hydraulic regime and physical nature of bottom sedimentation. University of Washington, Department of Oceanography, Tech. Rep. D-77-30. 327 pp.

Sternberg, R.W. and L.H. Larsen. - 1975. Threshold of sediment movement by open ocean waves: observations. Deep-Sea Res., 22: 299-309.

Sternberg, R.W. and L.H. Larsen. - 1976. Frequency of sediment movement on the Washington continental shelf: a note. Mar. Geol., 21: M37-M47.

Sternberg, R.W. and D.A. McManus. - 1972. Implications of sediment dispersal from long-term, bottom-current measurements on the continental shelf of Washington. In: Swift et al. (eds.), Shelf Sediment Transport: Process and Pattern, pp. 181-194. Dowden, Hutchinson and Ross, Inc., Stroudsburg, PA.

Sternberg, R.W., D.R. Morrison and J.A. Trimble. - 1973. An instrumentation system to measure near-bottom conditions on the continental shelf. Mar. Geol., 15: 181-189.

Sternberg, R.W. and A.R.M. Nowell. - 1999. Continental shelf sedimentology: scales of investigation define future research opportunities. J. Sea Res., 41: 55-71.

Sverdrup, H.U., M.W. Johnson and R.H. Fleming. - 1942. The Oceans, Their Physics, Chemistry, and General Biology. Prentice-Hall, Inc., Englewood Cliffs, NJ. 1087 pp.

Thomsen, L., G. Graf, V. Martens and E. Steen. - 1994. An instrument for sampling water from the benthic boundary layer. Cont. Shelf Res., 14: 871-882.

Traykovski, P., W.R. Geyer, J.D. Irish and J.F. Lynch. - 2000. The role of wave-induced density-driven fluid mud flows for crossshelf transport on the Eel River continental shelf. Cont. Shelf Res., 20: 2113-2140.

Trembanis, A.C., L.D. Wright, C.T. Friedrichs, M.O. Green and T. Hume. - 2004. The effects of spatially complex inner shelf roughness on boundary layer turbulence and current and wave friction: Tairua Embayment, New Zealand. Cont. Shelf Res., 24: 1549-1571.

Trowbridge, J.H. and G.C. Kineke. - 1994. Structure and dynamics of fluid muds on the Amazon continental shelf. J. Geophys. Res., 99: 865-874.

Van Weering, T.C.E. and I.N. McCave (guest eds.). - 2002. Benthic processes and dynamics at the NW Iberian Margin: results of the OMEX II program. Progr. Oceanogr.., 52: 121-476.

Vincent, C.E., D.J.P. Swift and B. Hillard. - 1981. Sediment transport in the New York Bight, North American Atlantic shelf. In: C.A. Nittrouer (ed.), Sedimentary Dynamics of Continental Shelves, 369-398. Mar. Geol., 42 (Special Issue).

Wheatcroft, R.A. and J.C. Borgeld. - 2000. Oceanic flood deposits on the northern California shelf: large-scale distribution and small-scale physical properties. Cont. Shelf Res., 20: 21632190.

Wheatcroft, R.A., C.K. Sommerfield, D.E. Drake, J.C. Borgeld and C.A. Nittrouer. - 1997. Rapid and widespread dispersal of flood sediment on the northern California margin. Geology, 25: 163-166.

White, C.M. - 1940. The equilibrium of grains on the bed of a stream. Proc. R. Soc., Ser. A, 174: 322-338.

Wiberg, P.S., D.E. Drake and D.A. Cacchione. - 1994. Sediment resuspension and bed armoring during high bottom stress events on the northern California continental shelf. Cont. Shelf Res., 14: 1191-1219.

Wiberg, P.L. and J.D. Smith. - 1983. A comparison of field data and theoretical models for wave-current interactions at the bed on the continental shelf. Cont. Shelf Res., 2: 147-162.

Williams III, A.J. - 1985. BASS, an acoustic current meter array for benthic flow-field measurements. Mar. Geol., 66: 345-355.

Wollast, R., L. Chou, B. Avril and J. Huthnance (guest eds.). 2001. Ocean Margin Exchange in the northern Gulf of Biscay: OMEX I. Deep-Sea Res. II, 48: 2971-3293. 
Wright, L.D., C.T. Friedrichs, S.C. Kim and M.E. Scully. - 2001. The effects of ambient currents and waves on gravity-driven sediment transport on continental shelves. Mar. Geol., 175: 25-45.

Wright, L.D., C.T. Friedrichs and M.E. Scully. - 2002. Pulsational gravity-driven sediment transport on two energetic shelves. Cont. Shelf Res., 22: 2443-2460.

Wright, L.D., S.C. Kim and C.T. Friedrichs. - 1999. Across-shelf variations in bed roughness, bed stress and sediment suspension on the northern California shelf. Mar. Geol., 154: 99-115.

Wright, L.D., L.C. Schaffner and J.P.Y. Maa. - 1997. Biological mediation of bottom boundary layer processes and sediment suspension in the lower Chesapeake Bay. Mar. Geol., 141: 27-50.

Wright, L.D., Z.S. Yang, B.D. Bornhold, G.H. Keller, D.B. Prior and W.J. Wiseman Jr. - 1986. Hyperpycnal plumes and plume fronts over the Huanghe (Yellow River) delta front. Geo-Mar. Lett.., 6: 97-105. 